\section{Production and Characterization of an Alkaline Lipase from Thermophilic Anoxybacillus sp. HBB16}

\author{
Z. Burcu Bakir* and K. Metin \\ Department of Biology, \\ Adnan Menderes University, \\ Aydın-09010, Turkey
}

doi: 10.15255/CABEQ.2016.990

Original scientific paper Received: October 7, 2016 Accepted: August 15, 2017

A thermophilic lipase-producing bacterium (Anoxybacillus sp. HBB16) was analyzed using $16 \mathrm{~S}$ rRNA. The maximum growth rate and intracellular lipase production occurred at $50{ }^{\circ} \mathrm{C}$ and $\mathrm{pH}$ 6.5. Among the various nitrogen and carbon sources tested, meat extract, olive oil and olive mill wastewater (OMW) were the best sources for lipase production. Enzyme production increased when the strain HBB16 was grown at a $180 \mathrm{rpm}$ shaking speed. The maximum activity of the lipase occurred at $55{ }^{\circ} \mathrm{C}$ and $\mathrm{pH} 9.5$. The presence of phenylmethylsulfonyl fluoride (PMSF), $N$-cyclohexyl- $N$ '-(2-morpholinoethyl) carbodiimidemetho- $p$-toluenesulfonate (CMC), N-bromosuccinimide (NBS) and sodium dodecyl sulfate (SDS) inhibited enzyme activity. Bivalent metal ions caused a significant inhibition in enzyme activity, whereas univalent metal ions displayed no negative effects.

Key words:

Anoxybacillus sp., lipase production, characterization, thermophilic, olive mill wastewater

\section{Introduction}

Lipase (triacylglycerol acylhydrolase; EC 3.1.1.3) enzymes catalyze the hydrolysis of mono-, di- and triacylglycerides to glycerol and free fatty acids at an oil-water interface. Lipases, due to their application in a wide range of industrial applications, have emerged as key enzymes in rapidly growing biotechnology. Lipases are widely used in biocatalysis due to their ability to catalyze not only the hydrolysis of triacylglycerides in aqueous solutions but also regio-, enantio- and stereoselective reactions in organic media. ${ }^{1}$ Lipases are widely distributed in animals, plants, and microorganisms. Among these sources, microbial enzymes are often considered more useful due to their high enzyme yields, great variety of catalytic activities, continuous availability due to the absence of seasonal fluctuations, ease of genetic manipulation, and rapid growth of microorganisms on inexpensive media. Moreover, the higher stability of microbial enzymes than corresponding plant and animal enzymes, and the convenience and safety of their production are advantageous. ${ }^{2}$ Enzymes from thermophilic organisms are more stable than similar enzymes from mesophilic organisms; therefore, they are more useful for biotechnological applications. Thermostable enzymes are important because they have a higher reaction rate at a higher operating temperature. Substrate solubility can increase at higher temperatures

*Corresponding author: zbakir@adu.edu.tr and thereby environmental contamination can be avoided.

Lipases are primarily responsible for the hydrolysis of acylglycerides at the lipid-water interface. On the other hand, lipases may catalyze the reverse reaction to produce glycerides from glycerol and fatty acids under suitable reaction conditions. ${ }^{3} \mathrm{Li}$ pases are extraordinary enzymes that can be used in organic solvents. Consequently, lipases have become the most widely used enzymes in various industrial applications and organic synthesis (i.e., food, oleochemical, detergent, pulp and paper industries, along with the resolution of chiral drugs, wastewater treatment, synthesis of peptides, and the production of biodiesel). ${ }^{2,4}$

The parameters that influence lipase production include type and concentration of the carbon and nitrogen sources, $\mathrm{pH}$ of the culture medium, temperature, and concentration of the dissolved oxygen in the fermentation medium. ${ }^{5}$ Furthermore, the presence of inhibitors, activators, stimulators and surfactants, in addition to the amount and source of inoculum, can also influence the production of lipases. ${ }^{6}$ Alternative industrial wastes constitute an important source to reduce the production costs of enzymes and enzyme products from microorganisms. One of these wastes, OMW, is a dark-colored effluent produced during the olive oil extraction process, and its inappropriate disposal is a serious environmental problem in Mediterranean countries. ${ }^{7,8,9}$ Sugars, nitrogen compounds, volatile acids, 
polyalcohols, pectins, oil, polyphenols and tannins providing the color for the olive mill wastewater constitute the main components of the effluent. ${ }^{10}$ These components could be a suitable liquid growth medium for lipase-producing microorganisms. ${ }^{8}$ There are many reports concerning the determination of the optimum culture conditions and nutritional requirements for lipase production. ${ }^{11,12,13} \mathrm{Ad}-$ ditionally, several fungi, yeast and bacteria have been reported to produce lipase in OMW-based media. ${ }^{7,89}$ There are very few reports concerning lipase-producing Anoxybacillus strains. Lipase from Anoxybacillus kamchatkensis, ${ }^{14}$ a lipase from $A n-$ oxybacillus flavithermus ${ }^{15}$ and lipases from different Anoxybacillus species ${ }^{16}$ have been reported. However, none of these studies has focused on the enhancement of lipase production.

This study aimed to determine various physical and chemical conditions required for the production of lipase in thermophilic Anoxybacillus sp. HBB16 and to use OMV as a source of carbon for lipase production.

\section{Materials and methods}

\section{Materials}

The reagents used in this study were of analytical grade and purchased from commercial sources at their highest purity.

\section{Microorganism}

The thermophilic bacterial strain HBB16 had been previously isolated from hot springs in Aydin/ Turkey by Dr. Gamze Başbülbül. The strain was grown on Luria-Bertani (LB) medium and stored at $-80{ }^{\circ} \mathrm{C}$ in a $20 \%$ skim milk solution.

\section{Identification of bacteria}

Genomic DNA of the strain was extracted using the partially modified phenol-chloroform method. ${ }^{17}$ The $16 \mathrm{~S}$ rRNA gene was amplified via PCR, and then the amplicon was sequenced. The primers used for amplification were: 341F (5'-CCT ACG GGA GGC AGC AG-3')-985R (5'-GTA AGG TTC GCG TT 3') and 20F (5'-AGA GTT TGA TCC TGG CTC AG-3')-1390R (5'-GAC GGG CGG TGT GTA CAA-3') (1300 bp). The PCR products were then directly sequenced in an ABI Prism 3730 XL Genetic analyzer by a professional company (Macrogen Inc., Korea) upon request. The 16S rRNA sequences were analyzed using the GenBank database (www.ncbi.nlm.nih.gov), and the identifications were made based on 16S rRNA sequence homology using the nucleotide-nucleotide BLAST (blastn) tool.

\section{Lipase activity}

A spectrophotometric assay was used for the determination of lipase activity using p-nitrophenyl laurate (pNPL) as substrate. ${ }^{18}$ The reaction mixture consisted of $0.1 \mathrm{~mL}$ of enzyme solution, $0.8 \mathrm{~mL}$ of $50 \mathrm{mM}$ Tris- $\mathrm{HCl}$ buffer ( $\mathrm{pH} 8.0)$, and $0.1 \mathrm{~mL}$ of 10 $\mathrm{mM}$ substrate (pNPL) solution in ethanol. The temperature was set to $55^{\circ} \mathrm{C}$, and the hydrolytic reaction was conducted for $30 \mathrm{~min}$. Following the incubation, $0.25 \mathrm{~mL}$ of $0.1 \mathrm{M} \mathrm{Na}_{2} \mathrm{CO}_{3}$ was added to stop the reaction. The mixture was centrifuged $(10000 \times g$, $15 \mathrm{~min}$ ) (Heraeus-Biofugepico, Germany), and the absorbance of the filtrate at $410 \mathrm{~nm}$ was measured. Using the p-nitrophenol molar absorption coefficient $\left(17.34 \mathrm{mM}^{-1} \mathrm{~cm}^{-1}\right)$, one unit of lipase enzyme activity was defined as the amount of enzyme responsible for the release of $1 \mu \mathrm{mol}$ p-nitrophenol from the pNP-laurate substrate in one minute under the defined experimental conditions.

\section{Protein determination}

Bradford's method was used to measure the protein concentration ${ }^{19}$, and bovine serum albumin was used as the standard.

\section{Cellular localization of lipase}

Anoxybacillus sp. HBB16 was cultivated in 50 $\mathrm{mL}$ of LB (Luria-Bertani) medium at $50{ }^{\circ} \mathrm{C}$ and at $\mathrm{pH} 6.5$ for $24 \mathrm{~h}$. For the detection of the cellular localization of the enzyme, the culture medium was centrifuged $\left(15 \mathrm{~min}, 20000 \times \mathrm{g}, 4^{\circ} \mathrm{C}\right)(\mathrm{Sigma}-3 \mathrm{~K} 30$, Germany), and the supernatant (S1) was stored for extracellular enzyme analysis. The cells were washed twice with ultra-pure water and re-suspended in an equal volume of Tris- $\mathrm{HCl}$ buffer $(20 \mathrm{mM}$, $\left.\mathrm{pH} 8.0,4{ }^{\circ} \mathrm{C}\right)(\mathrm{P} 1)$. A small volume of this fraction was reserved for the determination of enzyme activity in the intact cells. The cell suspension was sonicated in an ice bath for $10 \mathrm{~min}$ at $40 \%$ of the maximum power (BANDELIN SONOPULS-HD2200, Germany). The mixture was then centrifuged for 15 min at $4{ }^{\circ} \mathrm{C}$ and $20000 \times g$. The supernatant (S2) was separated and reserved for the measurement of the intracellular lipolytic activity. The disrupted cells were washed twice, re-suspended in an equal volume of Tris- $\mathrm{HCl}$ buffer $\left(20 \mathrm{mM}, \mathrm{pH} 8.0,4{ }^{\circ} \mathrm{C}\right)$ (P2) and stored for the detection of the cell membrane-bound enzyme activity.

\section{Time course of lipase production by Anoxybacillus sp. HBB16}

The growth curve of Anoxybacillus sp. HBB16 was determined at $50{ }^{\circ} \mathrm{C}$ and $\mathrm{pH} 6.5$ for 36 hours in an orbital shaker $(180 \mathrm{rpm})$. The $500-\mathrm{mL}$ flasks containing $100 \mathrm{~mL}$ of LB medium were inoculated 
$(1 \%, v / v)$ with a culture grown overnight whose OD was adjusted to 0.100 at $600 \mathrm{~nm}$. The culture was incubated for 36 hours in an orbital shaker (180 rpm). The growth curve of Anoxybacillus sp. HBB16 was determined by measuring the optical density during cell growth at $600 \mathrm{~nm}$ against the fresh medium. The lipase activity was also determined during cell growth. Three trials were conducted, and the average values were taken.

\section{Effect of physical parameters on lipase production}

The effect of temperature and $\mathrm{pH}$ on lipase production by Anoxybacillus sp. HBB16 was studied using LB medium at different temperatures (40-70 ${ }^{\circ} \mathrm{C}$ ) with the initial $\mathrm{pH}$ of 6.5 and at different initial $\mathrm{pH}$ values $(6.0-8.5)$ at $50{ }^{\circ} \mathrm{C}$.

The effect of agitation speed on lipase production by Anoxybacillus sp. HBB16 was studied using LB medium at different agitation speeds $(150,180$, 210 and $240 \mathrm{rpm}$ ). The $250-\mathrm{mL}$ flasks containing 50 $\mathrm{mL}$ of respective media were inoculated $(1 \%, \mathrm{v} / \mathrm{v})$ with a culture grown overnight whose OD was adjusted to 0.100 at $600 \mathrm{~nm}$. Next, the cultures were incubated at $50{ }^{\circ} \mathrm{C}$ and $\mathrm{pH} 6.5$ for 24 hours in an orbital shaker. After incubation, the lipase activity was determined. Three trials were conducted at each assay, and the average values were calculated.

\section{Effect of carbon and nitrogen sources on lipase production}

The effect of the type of carbon source on lipase production by Anoxybacillus sp. HBB16 was studied using LB containing various carbon sources (olive oil, cottonseed oil, corn oil, soybean oil, almond oil, and olive mill wastewater) at a concentration of $0.1 \%(\mathrm{v} / \mathrm{v})$. In the case of oils being used as the carbon source, $0.5 \%$ gum arabic was added to the LB medium.

The effect of the type of nitrogen source on lipase production by Anoxybacillus sp. HBB16 was studied using medium containing $0.1 \%$ olive oil, 1 $\% \mathrm{NaCl}$ and $0.5 \%$ gum arabic with various nitrogen sources (ammonium sulfate, casein hydrolysate, yeast extract, tryptone, peptone, and meat extract) at a concentration of $0.5 \%$.

The $250-\mathrm{mL}$ flasks containing $50 \mathrm{~mL}$ of respective media were inoculated $(1 \%, v / v)$ with a culture grown overnight whose absorbance was adjusted to 0.100 at $600 \mathrm{~nm}$. The cultures were incubated for $24 \mathrm{~h}$ in an orbital shaker $(150 \mathrm{rpm})$. Following incubation, the lipase activity was determined. Three trials were conducted at each carbon and nitrogen source, and the average values were considered.

\section{Temperature and $\mathrm{pH}$ effect on lipase activity}

The spectrophotometric enzyme assay was conducted at different temperatures $\left(5-80{ }^{\circ} \mathrm{C}\right)$ at $\mathrm{pH}$ 8.0 to determine the effect of temperature on lipase activity.

The effect of $\mathrm{pH}$ on Anoxybacillus sp. HBB16 lipase activity was assayed using a range of $\mathrm{pH}$ values (6.5-10.5). The potentiometric assay ( $\mathrm{pH}$-stat, Radiometer, Villeurbanne, France) was conducted by automatically titrating the free fatty acids liberated from tributyrin emulsion using a $0.01 \mathrm{~N} \mathrm{NaOH}$ solution. Tributyrin emulsion was prepared at a concentration of $1 \%$ in ultra-pure water containing $1 \%$ gum arabic and emulsified by homogenizing for 5 minutes. Fifteen milliliters of this substrate solution were transferred into the temperature-controlled vessel of the $\mathrm{pH}$-stat. The temperature and end-point $\mathrm{pH}$ value were adjusted to $55^{\circ} \mathrm{C}$ and the assay $\mathrm{pH}$, respectively. The reaction was initiated by adding $50 \mu \mathrm{L}$ of the enzyme, whose activity was then measured. Under the stated experimental conditions, the amount of enzyme responsible for the release of $1 \mu \mathrm{mol}$ of fatty acid per minute was defined as one unit of lipase.

\section{Effect of inhibitors and metal ions on lipase activity}

The effect of the inhibitors $\beta$-mercaptoethanol, PMSF, 1,4-dithiothreitol (DTT), NBS, CMC, SDS and metal ions $\left(\mathrm{FeCl}_{3}, \mathrm{AlCl}_{3}, \mathrm{HgCl}_{2}, \mathrm{MgCl}_{2}, \mathrm{ZnCl}_{2}\right.$, $\mathrm{CaCl}_{2}, \mathrm{CuCl}_{2}, \mathrm{MnCl}_{2}, \mathrm{BaCl}_{2}, \mathrm{CoCl}_{2}, \mathrm{KCl}, \mathrm{LiCl}$, $\mathrm{NaCl}, \mathrm{NiCl}_{2}, \mathrm{NH}_{4} \mathrm{Cl}, \mathrm{Na}_{2} \mathrm{O}_{3} \mathrm{Se}$ and EDTA) on lipase activity was studied. Lipase was incubated at $30^{\circ} \mathrm{C}$ for $30 \mathrm{~min}$ in the presence of 1 and $5 \mathrm{mM}$ of the aforementioned inhibitors or metal ions. Standard assay conditions were used for residual activity measurement. The activity of the enzyme without inhibitors and metal ions under the same experimental conditions was considered as $100 \%$.

\section{Results and discussion}

\section{Identification of the HBB16 strain}

The 16S rDNA sequence of the strain HBB16 showed the highest similarity with Anoxybacillus flavithermus (96\%), according to the BLAST results. The HBB16 strain was registered in the GenBank database system, from which the accession number KR911951 was obtained. The retrieved sequences were aligned using the Clustal $\mathrm{W}$ programand were manually edited. ${ }^{20}$ Phylogenetic trees were constructed by the neighbor-joining method using the Molecular Evolutionary Genetics Analysis version 4.0 (MEGA 4.0) ${ }^{21}$ (Fig. 1). 


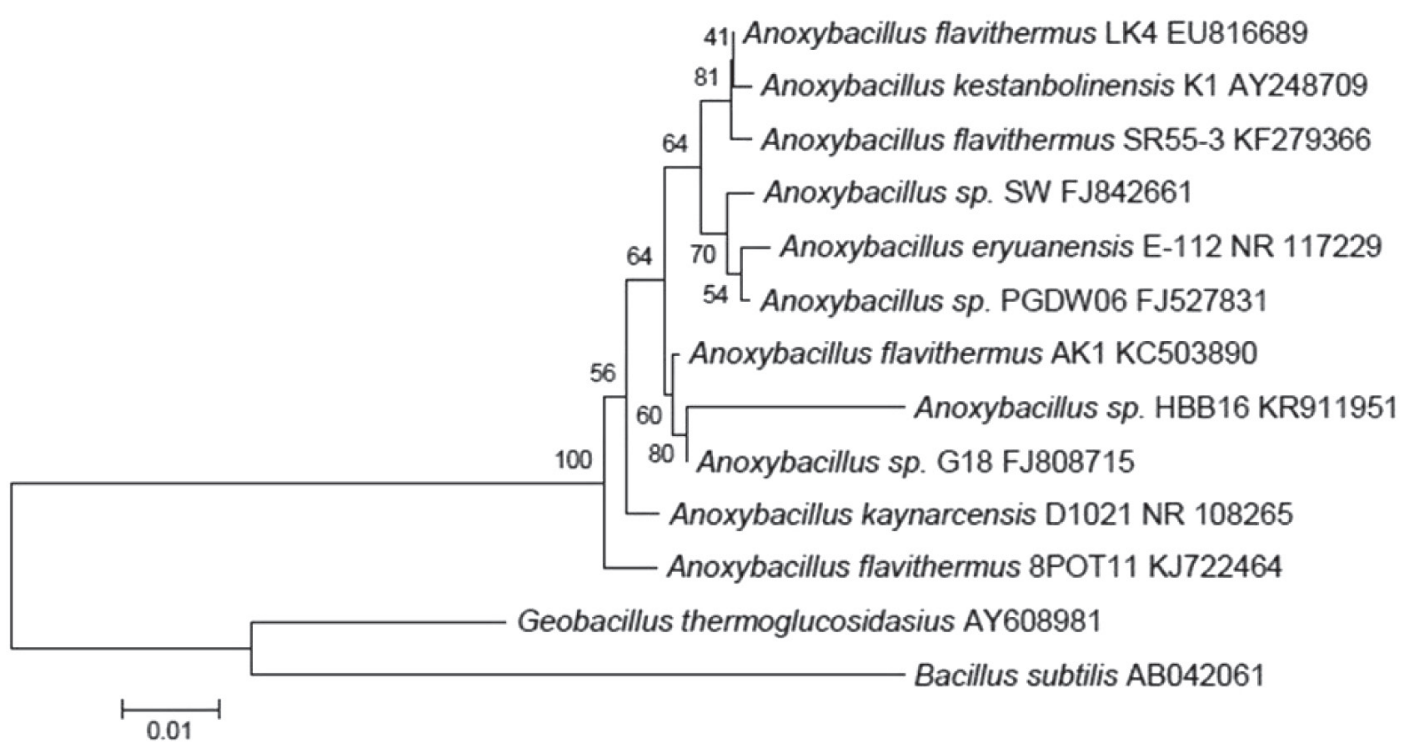

Fig. 1 - Phylogenetic tree resulting from the analysis of the $16 \mathrm{~S}$ rDNA sequences of Anoxybacillus sp. HBB16. The tree was constructed using the neighbor-joining method. The scale bar indicates a distance of 0.01 substitutions per site.

\section{Cellular localization of the lipase}

When the cellular localization of the lipase was investigated, most of the enzymatic activity was found in the intracellular fraction (S2) (Table 1). After cell breakage, the activity increased approximately $39 \%$. For this reason, the activity measurements of the culture condition effect were performed using unbroken cells. This observation indicated that the substrate passed through the cellular wall prior to hydrolysis. Previously conducted studies have also yielded similar results. ${ }^{22,23,24}$ Intracellular enzymes have some biotechnological superiorities over extracellular ones. Intracellular lipases are generally preferred as a direct source of enzyme for industrial applications because of the high-cost procedures of extraction, purification and the immobilization of extracellular enzymes. ${ }^{25}$

Table 1 - Cellular localization of lipase from Anoxybacillus sp. $H B B 16$

\begin{tabular}{cc}
\hline Fraction & Activity $\left(\mathrm{U} \mathrm{mL}^{-1}\right)$ \\
\hline Culture medium & 124.2 \\
S1 & 1.2 \\
P1 & 115.4 \\
S2 & 160.3 \\
P2 & 18.2 \\
\hline
\end{tabular}

Anoxybacillus sp. HBB16 was grown on LB medium at $50{ }^{\circ} \mathrm{C}$ and $\mathrm{pH} 6.5$ for $24 \mathrm{~h}$. S1 represents the culture supernatant; P1 represents intact cells; S2 represents the supernatant of broken cells; P2 represents broken cells.

\section{Time course of lipase production by Anoxybacillus sp. HBB 16}

The growth curve of Anoxybacillus sp. HBB16 was determined at $50{ }^{\circ} \mathrm{C}$ (optimum temperature for lipase production) and $\mathrm{pH} 6.5$ (optimum $\mathrm{pH}$ for lipase production) for 36 hours in an orbital shaker $(180 \mathrm{rpm})$. The lipase activity was also measured during cell growth. Anoxybacillus sp. HBB16 reached the logarithmic growth phase at $6 \mathrm{~h}$ and the stationary phase at $15 \mathrm{~h}$. The enzyme production started at the end of the logarithmic phase and reached a maximum in the middle $(21 \mathrm{~h})$ of the stationary phase (Data not shown). The $\mathrm{pH}$ value of the culture medium began to rise starting from the sixth hour when steady growth began reaching a value of 8.93 at the end of the thirty-sixth hour (Data not shown).

\section{Effect of the physical parameters on lipase production}

Temperature is an important physical parameter affecting microbial enzyme production. Anoxybacillus sp. HBB16 was grown at temperatures from 40 to $70{ }^{\circ} \mathrm{C}$ on LB medium. The isolate could not grow at $40{ }^{\circ} \mathrm{C}$, indicating that the organism was a thermophile rather than a thermotolerant bacterium. The growth of HBB16 increased with increasing temperatures starting at $45{ }^{\circ} \mathrm{C}$, and declined at $70{ }^{\circ} \mathrm{C}$ (Fig. 2a). The highest enzymatic production was attained at $50{ }^{\circ} \mathrm{C}$. Nevertheless, the activity results measured at $45{ }^{\circ} \mathrm{C}$ and $55{ }^{\circ} \mathrm{C}$ were $92 \%$ and $96 \%$ of the maximum activity, respectively. Thus, it may be proposed that HBB16 may be used for 
a)

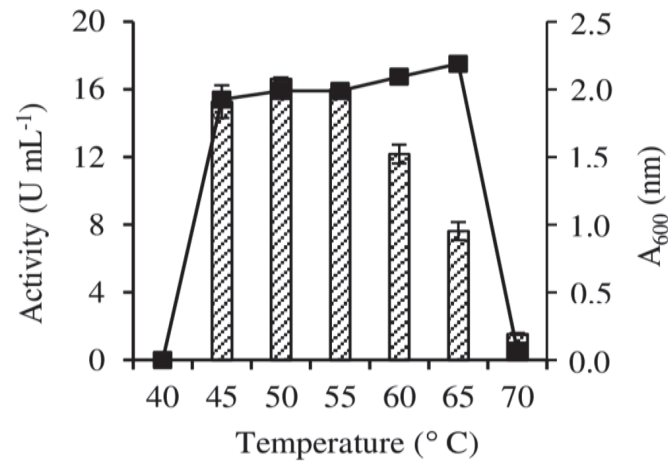

ECOC Activity $\longrightarrow-\mathrm{A}_{600}(\mathrm{~nm})$

b)

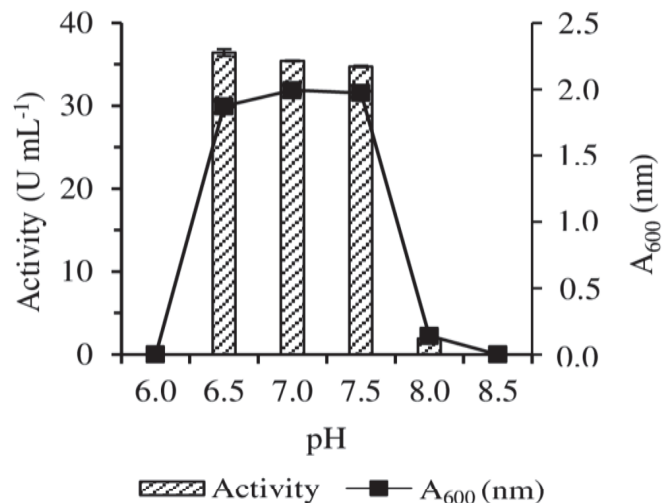

c)

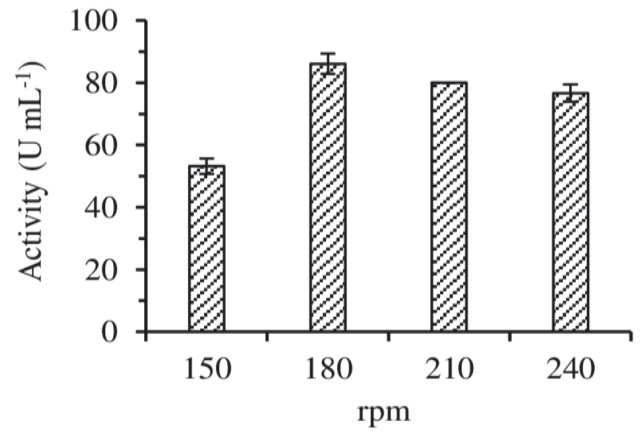

Fig. 2 - Effect of temperature, initial pH and agitation speed on lipase production a) Anoxybacillus sp. HBB16 was grown on $L B$ medium at different temperatures and $\mathrm{pH} 6.5$ for $24 \mathrm{~h} \mathrm{~b}$ ) Anoxybacillus sp. HBB16 was grown on LB medium at different $\mathrm{pHs}$ at $50{ }^{\circ} \mathrm{C}$ for $24 \mathrm{hc}$ c) Anoxybacillus sp. HBB16 was grown at $50^{\circ} \mathrm{C}$ and $\mathrm{pH} 6.5$ for $24 \mathrm{~h}$ on LB medium with different shaking speeds. The values are the means of three different cultures.

enzyme production in a range of temperatures between $45{ }^{\circ} \mathrm{C}$ and $55{ }^{\circ} \mathrm{C}$ (Fig. 2a). The bacterial growth was nearly the same at temperatures from 45 to $65{ }^{\circ} \mathrm{C}$, but the enzyme production decreased at 60 and $65^{\circ} \mathrm{C}$. It can be suggested that the reason for the decreased enzyme production may be a result of enzyme denaturation at high temperatures. Small differences in the $\mathrm{pH}$ of the environment may affect bacterial growth and enzyme production. The growth and enzyme production of Anoxybacillus sp. HBB16 were totally inhibited at pHs 6.0 and 8.5.
Maximum lipase production was detected when the initial $\mathrm{pH}$ was adjusted to $\mathrm{pH} 6.5$. However, $97 \%$ and $96 \%$ of the maximum activity detected at $\mathrm{pH}$ 7.0 and 7.5 , respectively, indicated that these $\mathrm{pHs}$ may also be used for enzyme production (Fig. 2b). Similar results have been obtained in the studies conducted using Anoxybacillus sp. HBB134. The isolate $\mathrm{HBB} 134$ showed maximum enzyme production at $45{ }^{\circ} \mathrm{C}$ and $\mathrm{pH}$ 6.5. ${ }^{23}$

Agitation rates influenced the lipase production of the HBB16 strain. When the shaking speed was increased from $150 \mathrm{rpm}$ to $180 \mathrm{rpm}$, the lipase activity increased 1.6-fold. However, at higher shaking rates (210 and $240 \mathrm{rpm})$, the lipase activity slightly decreased (Fig. 2c). The slight decrease in lipase activity at a higher agitation rate could be attributed to the hydrodynamic denaturation of enzymes caused by shear forces arising from mixing. The efficiency of lipase production could be due to the increased oxygen transfer rate and the increased surface area of contact with the media components. ${ }^{5}$ The increase in enzyme production at a higher shaking rate could be explained by the high production temperature $\left(50{ }^{\circ} \mathrm{C}\right)$ of HB16. Because the solubility of the gases is negatively correlated with the increase in temperature, the production medium should be well aerated to meet the oxygen needs of the bacteria.

\section{Effect of carbon and nitrogen sources on lipase production}

The carbon source has always been regarded as a major factor of lipase production. ${ }^{26}$ Lipases are inducible enzymes that are generally produced in the presence of oils as a carbon source. Lipidic carbon sources seem to be essential for obtaining a high lipase yield. ${ }^{26,27,28}$ The effect of lipids added to the medium to induce enzyme production varies from organism to organism. In accordance with this purpose, the addition of some natural oils and OMW was tested to determine their effect on the growth and lipase production of Anoxybacillus sp. HBB16 (Fig. 3a). However, the highest lipase activity was measured in the medium containing olive oil, and $94 \%$ of the enzyme production of the olive oil medium was observed in the medium containing OMW. This increase in enzyme activity could be attributed to the oil, sugars or nitrogen compounds present in the OMW. Because of the high enzyme production in the OMW medium, it can be suggested that OMW could be considered for lipase production. The improvement of the remediation and valorization of OMW would prevent environmental hazards and make an economical contribution.

Similarly, during the production of lipase by Penicillium restrictum ${ }^{28}$ and Bacillus sp. LBN $4^{27}$, the highest lipolytic activity was attained in media 
a)

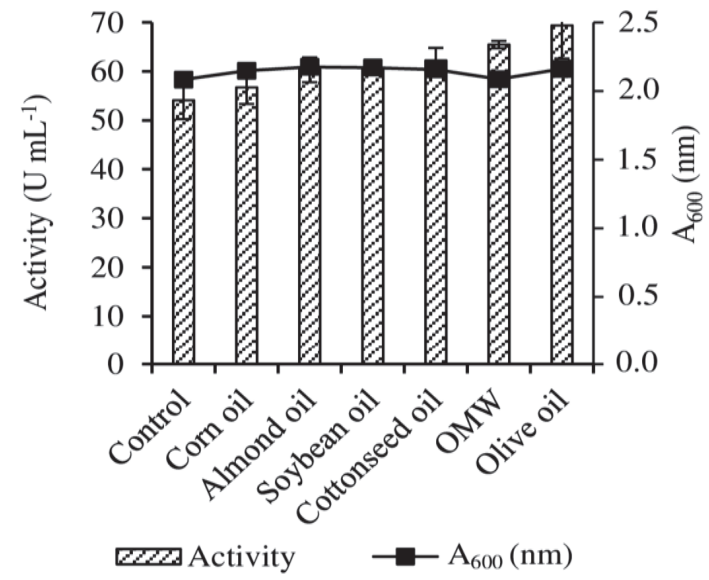

b)

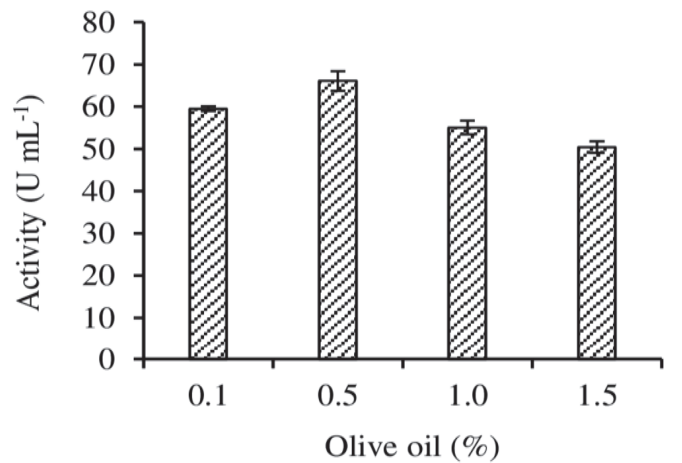

c)

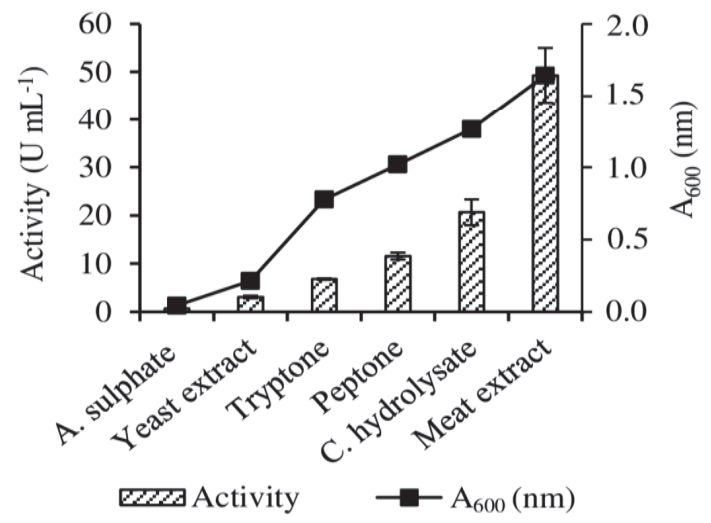

d)

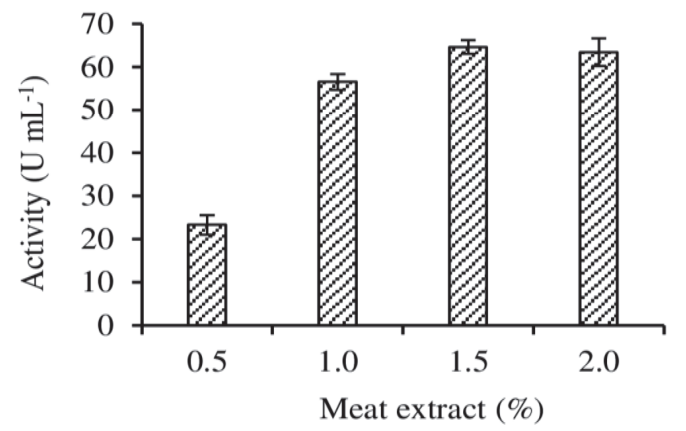

Fig. 3 - Effect of carbon and nitrogen sources on lipase production a) Anoxybacillus sp. HBB16 was grown at $50{ }^{\circ} \mathrm{C}$ and pH 6.5 for $24 \mathrm{~h}$ on LB medium containing $0.5 \%$ gum arabic with the addition of the indicated carbon source at a concentration of $0.1 \% \mathrm{~b}$ ) Effect of olive oil concentration on lipase production. Anoxybacillus sp. HBB16 was grown at $50^{\circ} \mathrm{C}$ and $\mathrm{pH} 6.5$ for $24 \mathrm{~h}$ on LB medium containing $0.5 \%$ gum arabic with the addition of olive oil at different concentrations c) Anoxybacillus sp. HBB 16 was grown at $50{ }^{\circ} \mathrm{C}$ and $\mathrm{pH} 6.5$ for $24 \mathrm{~h}$ on medium containing $0.1 \%$ olive oil, $1 \% \mathrm{NaCl}, 0.5 \%$ gum arabic with the addition of the indicated nitrogen source at a concentration of $0.5 \%$ d) Effect of meat extract concentration on lipase production. Anoxybacillus sp. HBB 16 was grown at $50{ }^{\circ} \mathrm{C}$ and $\mathrm{pH} 6.5$ for $24 \mathrm{~h}$ on medium containing $0.1 \%$ olive oil, $1 \% \mathrm{NaCl}, 0.5 \%$ gum arabic with the addition of meat extract at different concentrations. Values are the means of three different cultures.

containing olive oil. Ertuğrul et al. ${ }^{9}$ used OMW for the production of lipase along with other carbon sources, and determined that the best result in lipase production by Bacillus sp. was attained in a medium containing triolein. It had been previously reported that the highest amount of lipase production by $P$. camembertii Thom PG3 was attained in jojoba oil-containing media followed by olive oil-containing media. ${ }^{29}$

Various olive oil concentrations were also tested for lipase production (Fig. 3b). When the olive oil concentration was increased from $0.1 \%$ to 0.5 $\%$, the lipase activity increased. However, at higher concentrations (i.e., $1 \%$ and $1.5 \%$ ), the lipase activity slightly decreased. This result suggests that high concentrations of olive oil have an inhibitory effect on the lipase production of Anoxybacillus sp. HBB16. These results suggest that oleic acid released into the medium with a high olive oil concentration prevents either lipase biosynthesis or its cytotoxic effect on microorganisms. In addition, a high oil ratio in the medium could cause a reduction in the oxygen level in growth medium. These conclusions support the result showing an increase in enzyme production at a high agitation rate. ${ }^{26}$

Both organic and inorganic nitrogen sources are important for enzyme synthesis in microorganisms. Inorganic nitrogen sources are used quickly to meet the immediate nitrogen needs, whereas organic sources act as a supply for many cell growth factors and amino acids necessary for enzyme synthesis and cell metabolism. ${ }^{29}$

Organic nitrogen sources were usually preferred in studies reported in the literature. The best nitrogen source was reported to be $0.75 \%$ yeast extract for the production of lipase by Acinetobacter radioresistens ${ }^{11}, 0.2 \%$ peptone for the production of lipase by Bacillus megaterium AKG- $1^{30}, 0.5 \%$ peptone and $0.5 \%$ yeast extract for the production of lipase by Bacillus coagulans BTS-3 ${ }^{31}$, and $0.4 \%$ peptone and $0.2 \%$ yeast extract for the production of lipase by Stenotrophomonas maltophilia. ${ }^{13}$ 
It was observed that the production of lipase by Anoxybacillus sp. HBB16 is considerably affected by the type of nitrogen source. Additionally, it was observed that bacterial growth correlates well with the enzyme production but varies due to the nature of the nitrogen source (Fig. 3c). Ammonium sulfate was found to be the worse nitrogen source, whereas meat extract was found to be the best nitrogen source among the tested nitrogen sources for lipase production. For this reason, various meat extract concentrations were further tested (Fig. 3d). When the meat extract concentration was increased from $0.5 \%$ to $1 \%$, the lipase activity increased 2.4 -fold and reached a maximum at $1.5 \%$ meat extract.

\section{Temperature and pH effect on enzyme activity}

The effects of $\mathrm{pH}$ on HBB16 lipase activity were tested using the emulsion of tributyrin as a substrate with the $\mathrm{pH}$-stat method. The lipase showed activity at $\mathrm{pH}$ values between 6.5 and 10.5 (Fig. 4a), with the highest activity $(100 \%)$ at $\mathrm{pH}$ 9.5. The enzyme had no activity below $\mathrm{pH} 6.5$ or above $\mathrm{pH} 10.5$. Moreover, the enzyme maintained $86 \%, 90 \%$ and $74 \%$ of its maximum activity at $\mathrm{pH} 8.5,9.0$ and 10.0, respectively. It is known that lipases are active at alkaline pHs. Lipases from $\mathrm{Ba}$ cillus thermoleovorans CCR $11^{32}$ and Bacillus coagulans BTS- $3^{31}$ have an optimum activity at $\mathrm{pH} 9.0$ 10.0 and $\mathrm{pH} 8.5$, respectively. However, lipases that show activity at neutral and acidic pHs are also available. The present results prove that the enzyme under investigation is an alkaline lipase. Lipases that are stable under alkaline conditions are consid- ered promising candidates for the removal of fat stains in detergent formulations and for treating wastes from dairy industries.

The enzyme showed maximum activity at 55 ${ }^{\circ} \mathrm{C}$ and maintained $60 \%$ and $64 \%$ of its maximum activity at $45{ }^{\circ} \mathrm{C}$ and $50{ }^{\circ} \mathrm{C}$, respectively (Fig. 4b). These results are similar to those of Bacillus megaterium $\left(55^{\circ} \mathrm{C}\right)^{33}$, Bacillus sphaericus $205 \mathrm{y}\left(55^{\circ} \mathrm{C}\right)^{34}$ and Bacillus coagulans BTS-3 $\left(55^{\circ} \mathrm{C}\right)^{31}$. These results indicate that the enzyme may be useful for various processes such as detergent, leather, medical, cosmetic, textile and food industries ${ }^{2}$.

\section{Effect of metal ions and inhibitors on enzyme activity}

The effects of metal ions and inhibitors on the activity of the lipase are shown in Table 2. In most of the lipases and esterases, there is a serine residue located at the active site of the enzyme. ${ }^{35}$ However, lipases have lid structures that cover the entrance of the active site. Therefore, some lipases were not inhibited or were slightly inhibited by PMSF. ${ }^{36,37}$ HBB16 lipase activity decreased by approximately $95 \%, 78 \%$ and $70 \%$ in the presence of NBS, CMC and PMSF, respectively, suggesting the presence of tryptophan, carboxyl groups and serine residues at the active site of the enzyme. Because the enzyme activity was not inhibited by $\beta$-mercaptoethanolor DTT, we propose that sulfhydryl (SH-) and disulfide (-S-S-) groups in the active site of the enzyme are not present and are not participants in the catalysis processes. Similar results were found with Bacillus licheniformis ${ }^{38}$, Bacillus thermoleovorans

Table 2 - Effect of metal ions and inhibitors on enzyme activity

\begin{tabular}{lcclcc}
\hline & \multicolumn{2}{c}{ Residual enzyme activity (\%) } & & \multicolumn{2}{c}{ Residual enzyme activity (\%) } \\
\hline Additives & $1 \mathrm{mM}$ & $5 \mathrm{mM}$ & Additives & $1 \mathrm{mM}$ & $5 \mathrm{mM}$ \\
$\mathrm{Control}$ & 100 & 100 & $\mathrm{NiCl}_{2}$ & $16 \pm 0.01$ & $8.9 \pm 0.01$ \\
$\mathrm{NaCl}$ & $107 \pm 0.34$ & $76 \pm 0.02$ & $\mathrm{MnCl}_{2}$ & $14 \pm 1.25$ & $1.2 \pm 0.46$ \\
$\mathrm{KCl}$ & $107 \pm 0.10$ & $94 \pm 0.34$ & $\mathrm{CuCl}_{2}$ & $12 \pm 0.29$ & $1.5 \pm 0.06$ \\
$\mathrm{NH}_{4} \mathrm{Cl}$ & $101 \pm 0.22$ & $27 \pm 0.35$ & $\mathrm{HgCl}_{2}$ & $6 \pm 0.31$ & 0 \\
$\mathrm{LiCl}$ & $100 \pm 0.42$ & $27 \pm 0.15$ & $\mathrm{ZnCl}_{2}$ & $4.5 \pm 0.13$ & 0 \\
$\mathrm{Na}_{2} \mathrm{O}_{3} \mathrm{Se}$ & $75 \pm 0.01$ & $20 \pm 0.05$ & $\mathrm{EDTA}$ & $112 \pm 0.25$ & $110 \pm 0.10$ \\
$\mathrm{CaCl}_{2}$ & $68 \pm 0.07$ & $13 \pm 0.05$ & $\mathrm{PMSF}$ & $30 \pm 0.32$ & $4 \pm 0.04$ \\
$\mathrm{AlCl}_{3}$ & $48 \pm 0.62$ & $30 \pm 0.03$ & $\beta-\mathrm{mercaptothanole}$ & $97 \pm 1.06$ & $94 \pm 0.24$ \\
$\mathrm{BaCl}_{2}$ & $37 \pm 0.06$ & $28 \pm 0.03$ & $\mathrm{CMC}$ & $22 \pm 0.63$ & $30 \pm 0.07$ \\
$\mathrm{CoCl}_{2}$ & $29 \pm 0.03$ & $31 \pm 0.05$ & $\mathrm{NBS}$ & $5.2 \pm 0.29$ & 0 \\
$\mathrm{MgCl}_{2}$ & $28 \pm 0.32$ & $26 \pm 0.05$ & DTT & $97 \pm 1.01$ & $82 \pm 0.03$ \\
$\mathrm{FeCl}_{3}$ & $20 \pm 0.07$ & $0.1 \pm 0.04$ & SDS & $77 \pm 0.36$ & $11 \pm 0.27$ \\
\hline
\end{tabular}

The lipase was incubated at $30{ }^{\circ} \mathrm{C}$ for $30 \mathrm{~min}$ in the absence (control) and presence of additives at a final concentration of $1 \mathrm{M}$ and 5 $\mathrm{M}$. The lipase activities are expressed as the percentage of control, which was set as $100 \%$. All of the measurements are the means of three experimental data sets. 
a)

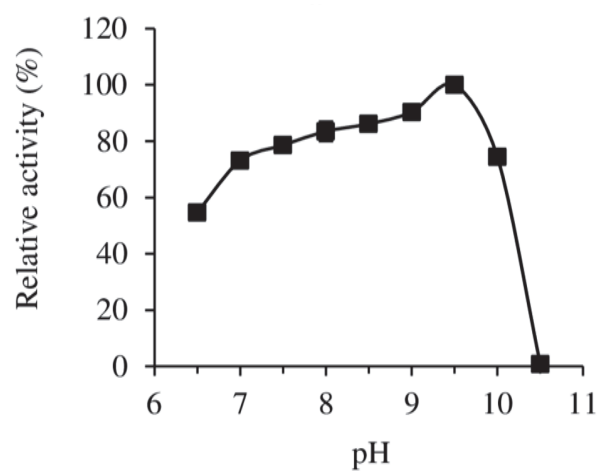

b)

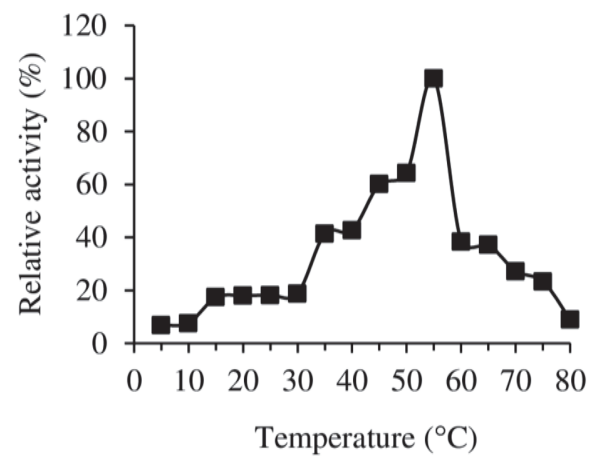

Fig. 4 - Effect of $p H$ and temperature on the activity of lipase from Anoxybacillus sp. HBB16 a) The effect of $\mathrm{pH}$ on the activity of the lipase. The lipase was incubated with substrate (triolein) at various pHs at $55{ }^{\circ} \mathrm{C} \mathrm{b}$ ) The effect of temperature on the activity of lipase. The lipase was incubated with substrate (pNPL) in $50 \mathrm{mM}$ Tris- $\mathrm{HCl}$ buffer ( $\mathrm{pH}$ 8.0) at various temperatures. All of the measurements are the means of three experimental data sets.

CCR1132, Bacillus sphaericus $205 \mathrm{y}^{34}$ and Bacillus licheniformis MTCC $6824^{39}$ lipases.

HBB16 lipase in the presence of $1 \mathrm{mM}$ univalent metal ions $\left(\mathrm{Na}^{+}, \mathrm{K}^{+}, \mathrm{Li}^{+}, \mathrm{NH}_{4}^{+}\right)$maintained its activity, but $5 \mathrm{mM} \mathrm{Li}^{+}$and $\mathrm{NH}_{4}^{+}$caused inhibition $(73 \%)$. Bivalent metal ions caused a dramatic inhibition in enzyme activity in 1- and 5-mM concentrations. Univalent metal ions had not displayed a negative effect on enzyme activity, presumably due to the weak attachment on the enzyme surface and active site. Because bivalent metal ions tightly attach, especially to amino acids with carboxyl groups (aspartic acid and glutamic acid residue), we suggest that they cause a decrease in lipase activity because of changes in the enzyme conformation or by blocking the binding of the substrate to the active site.

These results support our proposal suggesting that the presence of carboxyl groups in the active site of the enzyme is responsible for its activity. Because lipase activity increased approximately $10 \%$ after incubation with EDTA, the lipase is not a metalloenzyme. The increase in the enzyme activity in the presence of EDTA is probably due to the binding of metal ions by EDTA. Similar to HBB16 lipase, lipases of Bacillus sp. ${ }^{40}$, Bacillus thermoleov- orans CCR $11^{32}$ and Acinetobacter sp. RAG-1 $1^{37}$ were inhibited by $\mathrm{Hg}^{2+}$. It was reported that lipases of Pseudomonas aeruginosa PseA $^{36}$ and Aspergillus carneus $^{41}$ had also conserved their activities against EDTA.

\section{Conclusions}

In this study, medium components (carbon and nitrogen sources), initial $\mathrm{pH}$ and incubation temperature were examined for the optimization of lipase production of thermophilic Anoxybacillus sp. HBB 16. The results of this study indicate that HBB 16 can produce lipase efficiently in a wide temperature and $\mathrm{pH}$ range (between $45{ }^{\circ} \mathrm{C}-55^{\circ} \mathrm{C}$ and $\mathrm{pH}$ 6.5-7.5). However, the agitation rate and meat extract concentration also enhanced lipase production significantly. Alternative industrial wastes constitute an important source to reduce the production costs of enzymes and enzyme products from microorganisms. OMW, a waste product, was also used as a carbon source in lipase production and high enzyme production was observed in this medium. The maximum activity of the HBB 16 lipase occurred at $55^{\circ} \mathrm{C}$ and $\mathrm{pH} 9.5$ indicates that the enzyme may be useful for various industrial processes.

\section{ACKNOWLEDGEMENTS}

This work was part of the research projects "Purification and characterization of lipase enzyme from Anoxybacillus sp. HBB16", funded by the Adnan Menderes University Scientific Research Foundation (FEF 14004). The authors are grateful to Dr. Gamze Başbülbül, Department of Biology, Adnan Menderes University, Turkey, for her kind gift of microbial strains, and to Dr. Bülent Bozdoğan, Department of Microbiology, Adnan Menderes University, Turkey, for his contributions to the molecular identification of the microbial strain.

\section{References}

1. Dheeman, D. S., Frias, J. M., Henehan, G. T. M., Influence of cultivation conditions on the production of a thermostable extracellular lipase from Amycolatopsis mediterranei DSM 43304, J. Ind. Microbiol. Biotechnol. 37 (2010) 1. doi: https://doi.org/10.1007/s10295-009-0643-7.

2. Hasan, F., Shah, A. A., Hameed. A., Industrial applications of microbial lipases, Enzyme Microb. Technol. 39 (2006) 235. doi: https://doi.org/10.1016/j.enzmictec.2005.10.016.

3. Saxena, R., Ghosh, P. K., Gupta, R., Sheba Davidson, W., Bradoo, S., Gulati, R., Microbial lipases: Potential biocatalysts for the future industry, Curr. Sci. 77 (1999) 101.

4. Sharma, R., Chisti, Y., Banerjee, U. C., Production, purification, characterization, and applications of lipases, Biotechnol. Adv. 19 (2001) 627. doi: https://doi.org/10.1016/S0734-9750(01)00086-6. 
5. Elibol, M., Ozer, D., Influence of oxygen transfer on lipase production by Rhizopus arrhizus, Process Biochem. 36 (2000) 325 . doi: https://doi.org/10.1016/S0032-9592(00)00226-0.

6. Hasan, F., Shah, A. A., Hameed, A., Methods for detection and characterization of lipases: A comprehensive review, Biotechnol. Adv. 27 (2009) 782. doi: https://doi.org/10.1016/j.biotechadv.2009.06.001.

7. Lanciotti, R., Gianotti, A., Baldi, D., Angrisani, R., Suzzi, G., Mastrocola, D., Guerzoni, M. E., Use of Yarrowia lipolytica strains for the treatment of olive mill wastewater, Bioresour. Technol. 96 (2005) 317. doi: https://doi.org/10.1016/j.biortech.2004.04.009.

8. Brozzoli, V., Crognale, S., Sampedro, I., Federici, F., D'Annibale, A., Petruccioli, M., Assessment of olive-mill wastewater as a growth medium for lipase production by Candida cylindracea in bench-top reactor, Bioresour. Technol. 100 (2009) 3395. doi: https://doi.org/10.1016/j.biortech.2009.02.022.

9. Ertuğrul, S., Dönmez, G., Takaç, S., Isolation of lipase producing Bacillus sp. from olive mill wastewater and improving its enzyme activity, J. Hazard. Mater. 149 (2007) 720. doi: https://doi.org/10.1016/j.jhazmat.2007.04.034.

10. Rozzi, A., Malpei, F., Treatment and disposal of olive mill effluents, Int. Biodeterior. Biodegradation 38 (1996) 135. doi: https://doi.org/10.1016/S0964-8305(96)00042-X.

11. Li, C. Y., Cheng, C. Y., Chen, T. L., Fed-batch production of lipase by Acinetobacter radioresistens using Tween 80 as the carbon source, Biochem. Eng. J. 19 (2004) 25. doi: https://doi.org/10.1016/j.bej.2003.09.006.

12. Maldonado, R. R., Macedo, G. A., Rodrigues, M. I., Lipase production using microorganisms from different agro-industrial by-products, Int. J. Appl. Sci. Technol. 4 (2014) 108.

13. Hasan-Beikdashti, M., Forootanfar, H., Safiarian, M. S., Ameri, A., Ghahremani, M. H., Khoshayand, M. R., Faramarzi, M. A., Optimization of culture conditions for production of lipase by a newly isolated bacterium Stenotrophomonas maltophilia, J. Taiwan Inst. Chem. Eng. 43 (2012) 670 doi: https://doi.org/10.1016/j.jtice.2012.03.005.

14. Olusesan, A. T., Azura, L. K., Abubakar, F., Hamid, N. S. A., Radu, S., Saari, N., Phenotypic and molecular identification of a novel thermophilic Anoxybacillus species: A lipase-producing bacterium isolated from a Malaysian hotspring, World J. Microbiol. Biotechnol. 25 (2009) 1981. doi: https://doi.org/10.1007/s11274-009-0097-0.

15. Zuridah, H., Norazwin, N., Siti Aisyah, M., Fakhruzzaman, M. N. A., Zeenathul, N. A., Identification of lipase producing thermophilic bacteria from Malaysian hot springs, African J. Microbiol. Res. 21 (2011) 3569. doi: https://doi.org/10.5897/AJMR11.777.

16. Pinzón-Martínez, D. L., Rodríguez-Gómez, C., Miñana-Galbis, D., Carrillo-Chávez, J., Valerio-Alfaro, G., Oliart-Ros, R., Thermophilic bacteria from Mexican thermal environments: isolation and potential applications, Environ. technol. 31 (2010) 957. doi: https://doi.org/10.1080/09593331003758797.

17. Ronimus, R. S., Parker, L. E., Morgan, H. W., The utilization of RAPD-PCR for identifying thermophilic and mesophilic Bacillus species, FEMS Microbiol. Lett. 147 (1997) 75. doi: https://doi.org/10.1016/S0378-1097(96)00507-1.

18. Sigurgisladottir, S., Konraosdottir, M., Jonsson, A., Kristjansson, J. K., Matthiasson, E., Lipase activity of thermophilic bacteria from icelandic hot-springs, Biotechnol. Lett. 15 (1993) 361.

doi: https://doi.org/10.1007/Bf00128277.
19. Bradford, M. M., A rapid and sensitive method for the quantitation of microgram quantities of protein utilizing the principle of protein-dye binding, Anal. Biochem. 72 (1976) 248.

doi: https://doi.org/10.1016/0003-2697(76)90527-3.

20. Thompson, J. D., Higgins, D. G., Gibson, T. J., Clustal, W., Improving the sensitivity of progressive multiple sequence alignment through sequence weighting, position-specific gap penalties and weight matrix choice, Nucleic Acids Res. 22 (1994) 4673. doi: https://doi.org/10.1093/nar/22.22.4673

21. Tamura, K., Stecher, G., Peterson, D., Filipski, A., Kumar, S., MEGA6: Molecular evolutionary genetics analysis version 6.0, Mol. Biol. Evol. 30 (2013) 2725. doi: https://doi.org/10.1093/molbev/mst197.

22. Kademi, A., Ait-Abdelkader, N., Fakhreddine, L., Baratti, J. $C$., A thermostable esterase activity from newly isolated moderate thermophilic bacterial strains, Enzyme Microb. Technol. 24 (1999) 332.

doi: https://doi.org/10.1016/S0141-0229(98)00127-6.

23. Bakir, Z. B., Metin, K., Screening for industrially important enzymes from thermophilic bacteria; selection of lipaseproducing microorganisms and optimization of culture conditions, Eur. J. Biotechnol. Biosci. 3 (2015) 43.

24. Kakariari, E., Georgalaki, M. D., Kalantzopoulos, G., Tsakalidou, E., Purification and characterization of an intracellular esterase from Propionibacterium freudenreichii ssp. freudenreichii ITG 14, Lait. 80 (2000) 491. doi: https://doi.org/10.1051/lait:2000140.

25. Andualema, B., Gessesse, A., Microbial lipases and their industrial applications: Review, Biotechnology 11 (2012) 100. doi: https://doi.org/10.3923/biotech.2012.100.118.

26. Zarevúcka, M., Olive Oil as Inductor of Microbial Lipase, Olive Oil - Constituents, Quality, Health Properties and Bioconversions, Dimitrios B. (Ed.), InTech, Croatia, 2012, pp 457-470.

27. Bora, L., Kalita, M., Production and optimization of thermostable lipase from a thermophilic Bacillus sp LBN 4, Internet J. Microbiol. 4 (2006) 1.

28. De Azeredo, L. A. I., Gomes, P. M., Sant'Anna, G. L., Castilho, L. R., Freire, D. M. G., Production and regulation of lipase activity from Penicillium restrictum in submerged and solid-state fermentations, Curr. Microbiol. 54 (2007) 361. doi: https://doi.org/10.1007/s00284-006-0425-7.

29. Tan, T., Zhang, M., Xu, J., Zhang, J., Optimization of culture conditions and properties of lipase from Penicillium camembertii Thom PG-3, Process Biochem. 39 (2004) 1495 . doi: https://doi.org/10.1016/S0032-9592(03)00296-6.

30. Sekhon, A., Dahiya, N., Tewari, R. P., Hoondal, G. S., Production of extracellular lipase by Bacillus megaterium AKG-1 in submerged fermentation, Indian J. Biotechnol. 5 (2006) 179.

31. Kumar, S., Kikon, K., Upadhyay, A., Kanwar, S. S., Gupta, $R$., Production, purification, and characterization of lipase from thermophilic and alkaliphilic Bacillus coagulans BTS-3, Protein Expr. Purif. 41 (2005) 38. doi: https://doi.org/10.1016/j.pep.2004.12.010.

32. Castro-Ochoa, L. D., Rodríguez-Gómez, C., Valerio-Alfaro, $G$., Oliart Ros, R., Screening, purification and characterization of the thermoalkalophilic lipase produced by Bacillus thermoleovorans CCR11, Enzyme Microb. Technol. 37 (2005) 648. doi: https://doi.org/10.1016/j.enzmictec.2005.06.003. 
33. Lima, V. M. G., Krieger, N., Mitchell, D. A., Baratti, J. C., Filippis, I., Fontana, J. D., Evaluation of the potential for use in biocatalysis of a lipase from a wild strain of Bacillus megaterium, J. Mol. Catal. B: Enzym. 31 (2004) 53. doi: https://doi.org/10.1016/j.molcatb.2004.07.005.

34. Sulong, M. R., Abdul Rahman, R. N. Z. R., Salleh, A. B., Basri, M., A novel organic solvent tolerant lipase from $B a$ cillus sphaericus 205y: extracellular expression of a novel OST-lipase gene, Protein Expr. Purif. 49 (2006) 190. doi: https://doi.org/10.1016/j.pep.2006.04.015.

35. Fojan, $P$., What distinguishes an esterase from a lipase: A novel structural approach, Biochimie 82 (2000) 1033. doi: https://doi.org/10.1016/S0300-9084(00)01188-3.

36. Gaur, R., Gupta, A., Khare, S. K., Purification and characterization of lipase from solvent tolerant Pseudomonas aeruginosa PseA, Process Biochem. 43 (2008) 1040. doi: https://doi.org/10.1016/j.procbio.2008.05.007.

37. Snellman, E. A., Sullivan, E. R., Colwell, R. R., Purification and properties of the extracellular lipase, LipA, of Acinetobacter sp. RAG-1, Eur. J. Biochem. 269 (2002) 5771. doi: https://doi.org/10.1046/j.1432-1033.2002.03235.x.
38. Nthangeni, M. B., Patterton, H. G., van Tonder, A., Vergeer W. P., Litthauer, D., Over-expression and properties of a purified recombinant Bacillus licheniformis lipase: a comparative report on Bacillus lipases, Enzyme Microb. Technol. 28 (2001) 705.

doi: https://doi.org/10.1016/S0141-0229(01)00316-7.

39. Chakraborty, K., Raj, R. P., An extra-cellular alkaline metallolipase from Bacillus licheniformis MTCC 6824: Purification and biochemical characterization, Food Chem. 109 (2008) 727. doi: https://doi.org/10.1016/j.foodchem.2008.01.026.

40. Nawani, N., Kaur, J., Studies on lipolytic isoenzymes from a thermophilic Bacillus sp.: Production, purification and biochemical characterization, Enzyme Microb. Technol. 40 (2007) 881. doi: https://doi.org/10.1016/j.enzmictec.2006.07.006.

41. Saxena, R., Davidson, W., Sheoran, A., Giri, B., Purification and characterization of an alkaline thermostable lipase from Aspergillus carneus, Process Biochem. 39 (2003) 239. doi: https://doi.org/10.1016/S0032-9592(03)00068-2. 